\title{
STUDIES ON BRYOZOA.
}

Part $2 .{ }^{1}$

BY

Rex W. Bretnall, late Invertebrate Zoologist, The Australian Museum.

(Figures 1-2.)

1. On a Collection of Bryozoa from 26-38 fathoms off Norah Head, NEW Sodth WaLes.

By the courtesy of Mr. A. P. Summergreene, General Manager of the State Trawling Industry, Messrs. F. A. McNeill and A. A. Livingstone, of the Australian Museum, were afforded the opportunity of accompanying the State trawler "Goonambee" on her cruise of June 15-19, 1921. Among the material obtained from the trawl was a small collection of Bryozoa, which is interesting since it includes two new species, and also forms that have not hitherto been recorded from the coast of New South Wales. The collection contains :-

Catenaria cornuta Busk.

Caberea grandis Hincks.

Bugularia dissimilis MacGillivray.

Porina larvalis MacGillivray.

Craspedozoum roboratum Hincks.

Lunularia rubra sp. nov.

Conescharellina magniarmata Maplestone.

, philippinensis Busk.

, conica Haswell.

Selenaria livingstonei sp. nov.

Retepora monilifera MacGillivray, form munita Hincks.

Adeonellopsis foliacea MacGillivray.

Some interesting forms of a new species of Bipora are also in the collection, but the description of this species which is being dealt with elsewhere, is not included here.

Lunularia rubra sp. nov.

(Fig. 1.)

Polyzoary.-A top-shaped structure with a flat base, $3.5 \mathrm{~mm}$. in height and $4 \mathrm{~mm}$. at the diameter of the base.

Diagnosis.-The zoccia are roundly quadrangular and are arranged in radiating rows. The orifice, enclosed in a sloping peristome, is orbicular in shape and is protected by a yellowish operculum. The areas between

1 For Part 1 see Records of the Australian Museum, Vol. xiii., No. 4, 1921, p. 157. 